\title{
Consumption of $\mathrm{H}_{2} \mathrm{~S}$ from Our Daily Diet: Determination by a Simple Chemosensing Method
}

\author{
Ayndrila Ghosh, ${ }^{\dagger}$ Sujoy Das, ${ }^{\dagger}$ Himadri S. Sarkar, ${ }^{\circledR}$ Shampa Kundu, and Prithidipa Sahoo*(1) \\ Department of Chemistry, Visva-Bharati University, Santiniketan 731235, W.B., India \\ Supporting Information
}

ABSTRACT: A unique method has been developed for comparative analysis of $\mathrm{H}_{2} \mathrm{~S}$ produced from food samples from our daily diet, both qualitatively and quantitatively. The selective detection of $\mathrm{H}_{2} \mathrm{~S}$ has been executed by introducing a simple chemodosimeter $\left(\mathbf{P N}-\mathbf{N}_{3}\right)$ that gives response on the basis of intramolecular charge transfer. UV-vis, fluorimetric, and NMR titrations were performed to demonstrate the sensing mechanism and electronic environment of $\mathbf{P N}-\mathbf{N}_{3}$ in the presence of $\mathrm{H}_{2} \mathrm{~S}$. Density functional theory calculations were performed to validate the mechanism of azide $\left(\mathbf{P N}-\mathbf{N}_{3}\right)$ reduction to amine $\left(\mathbf{P N}-\mathbf{N H}_{2}\right)$ by the strong reducing power of $\mathrm{H}_{2} \mathrm{~S}$. The potentiality of this chemosensing method is that it could be treated as a simple, less-time-consuming, and cost-effective method for determining $\mathrm{H}_{2} \mathrm{~S}$ in biological samples in the nanomolar range.

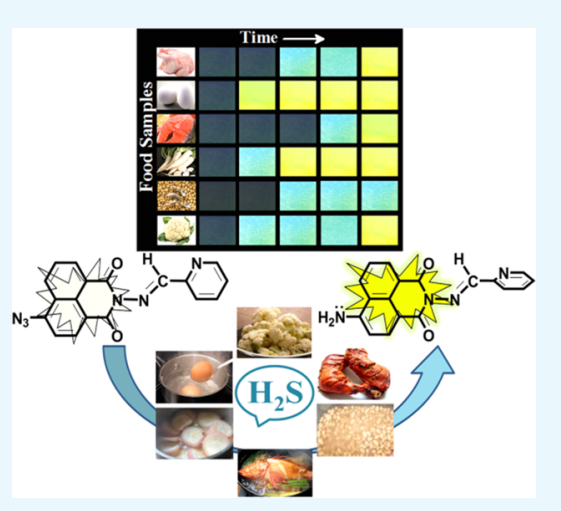

\section{INTRODUCTION}

Hydrogen sulfide $\left(\mathrm{H}_{2} \mathrm{~S}\right)$ gas is though traditionally recalled with its unique obnoxious foul smell of rotten eggs, ${ }^{1,2}$ but nowadays it is in the limelight of scientific research field for its role as third endogenous gasotransmitter, after carbon monoxide (CO) and nitric oxide (NO).$^{3-7}$ In a mammalian system, $\mathrm{H}_{2} \mathrm{~S}$ is endogenously produced from cysteine (Cys) and homocysteine (Hcy) in a series of reactions mainly catalyzed by several enzymes: two pyridoxal-5'-phosphate (PLP)-dependent enzymes, cystathionine $\beta$-synthase (CBS $)^{8}$ and cystathionine $\gamma$-lyase (CSE), ${ }^{9}$ as well as cysteineaminotransferase (CAT) and mercaptopyruvatesulfurtransferase (MST) ${ }^{10,11}$ Some sulfate-reducing bacteria, present in both the mouth and intestinal tract, ${ }^{12}$ can oxidize organic compounds or molecular hydrogen while reducing $\mathrm{SO}_{4}{ }^{2-}$ to $\mathrm{H}_{2} \mathrm{~S}$. The biological concentration level of $\mathrm{H}_{2} \mathrm{~S}$ in blood plasma is $10-100 \mu \mathrm{M}$, whereas in the central nervous system, it is found to be in the range of $50-160 \mu \mathrm{M} \cdot{ }^{13,14} \mathrm{~A}$ number of pathological and physiological $^{15-18}$ processes, especially modulation of gastrointestinal, endocrine, and genitourinary systems $^{19-23}$ and neuromodulation, ${ }^{24-26}$ possess direct involvement of $\mathrm{H}_{2} \mathrm{~S}$. Besides these, $\mathrm{H}_{2} \mathrm{~S}$ can also act as a channel opener of adenosine 5 'triphosphate (ATP)-sensitive potassium channels $\left(\mathrm{K}_{\mathrm{ATP}}\right)$ and some other potassium channels ${ }^{27,28}$ and as an antioxidant or scavenger toward reactive oxygen species (ROS). ${ }^{29}$ Numerous diseases show correlation with the abnormal level of $\mathrm{H}_{2} \mathrm{~S}$ regulation in the mammalian body system. $^{30-33}$

Along with this entire beneficial role, $\mathrm{H}_{2} \mathrm{~S}$, if present in higher concentration, can also be deadly harmful for the biological system by inducing shock, coma, and convulsion. ${ }^{34}$ Due to the power of reducibility and high solubility in lipids even at low concentration, ${ }^{35} \mathrm{H}_{2} \mathrm{~S}$ may prevent cellular respiration through complexation with cytochromes, which eventually leads to death. ${ }^{36}$ It is found that the $\beta$ cells of pancreas in type 1 diabetes ${ }^{37}$ and human body inherited with trisomy 21 (Down's syndrome) ${ }^{38}$ produces an excess of this gas. The manifestation of both advantageous and adverse effects of $\mathrm{H}_{2} \mathrm{~S}$ undoubtedly demands that certain biological concentration level of this gas must be maintained in our body.

To the best of our knowledge, the quantitative estimation of $\mathrm{H}_{2} \mathrm{~S}$ from food samples using the chemodosimetric method has not been studied so far, even though one of the main sources from which endogenous $\mathrm{H}_{2} \mathrm{~S}$ is produced is food what we consume daily (comparison table, Table S1). Our research group has developed a unique method to monitor the comparative concentration of $\mathrm{H}_{2} \mathrm{~S}$ in our daily diet. In this method, a new chemodosimetric probe, pyridine-naphthalimide conjugated azide $\left(\mathbf{P N}-\mathbf{N}_{3}\right)$, has been introduced to detect the gas very promptly through the fluorescence "turn-on" mechanism. Several traditional analytical methods, such as electrochemical methods, ${ }^{39-42}$ gas chromatography, ${ }^{43-45}$ colorimetric assay, ${ }^{46-48}$ and metal-induced sulfide precipitation $^{49,50}$ have been used for detection of $\mathrm{H}_{2} \mathrm{~S}$. However, we took interest in chemosensors due to their high sensitivity, high quantum yield (QY, $\Phi)$, selectivity, and specificity toward the guest, and more significantly these probes are of low cost, ${ }^{51-55}$ portable and able to sense the target molecules in very less time. For designing the probes to detect $\mathrm{H}_{2} \mathrm{~S}$, the azide $-\mathrm{H}_{2} \mathrm{~S}$ reaction chemistry is predominantly explored. ${ }^{56-60}$ Keeping in mind this mechanism, $\mathbf{P N}-\mathbf{N}_{3}$ was synthesized with $86 \%$ yield through three simple steps of reactions starting from 4-bromo-

Received: July 23, 2018

Accepted: September 10, 2018

Published: September 21, 2018 

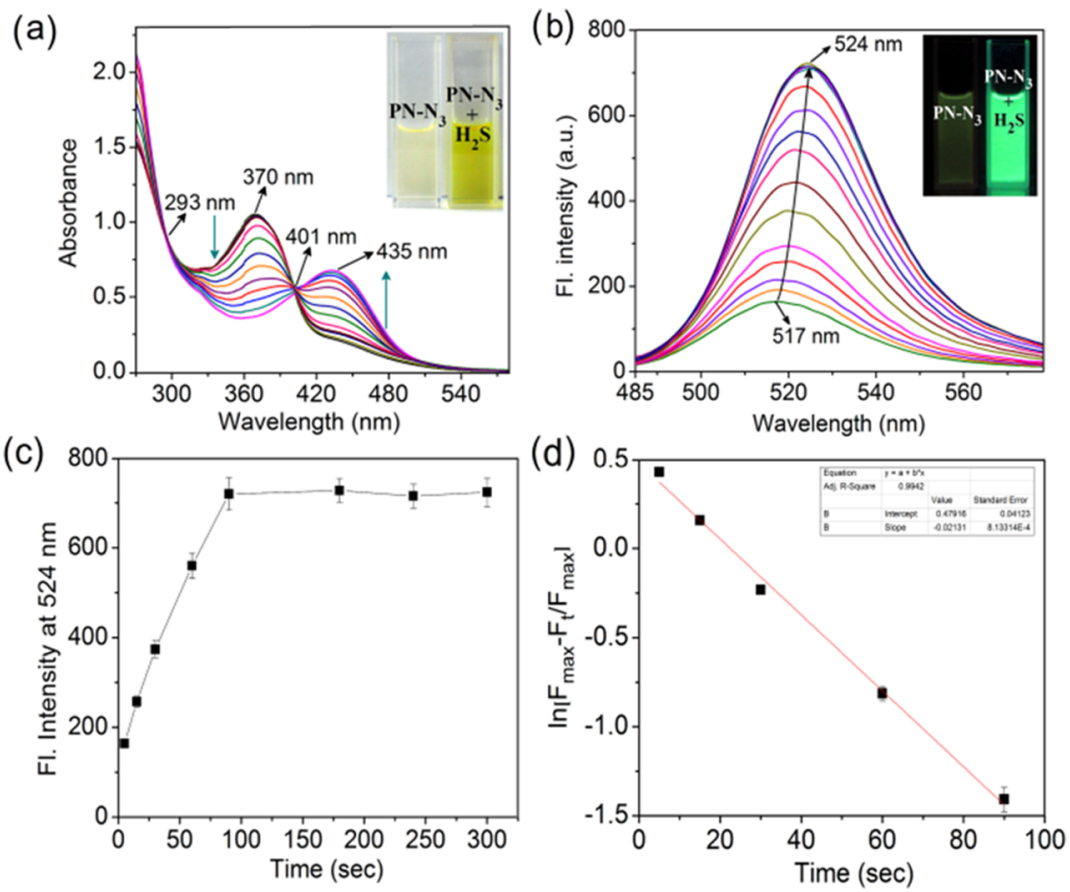

Figure 1. (a) UV-vis absorption spectra of $\mathbf{P N}-\mathrm{N}_{3}(20 \mu \mathrm{M})$ upon addition of $\mathrm{H}_{2} \mathrm{~S}$ up to 20 equiv in $\mathrm{CH}_{3} \mathrm{CN} / \mathrm{H}_{2} \mathrm{O}(1: 8, \mathrm{v} / \mathrm{v} ; \mathrm{pH} 7.0 ; 10 \mathrm{mM}$ phosphate buffer). (Inset) Visual changes of $\mathbf{P N}-\mathbf{N}_{3}$ after addition of $\mathrm{H}_{2} \mathrm{~S}$. (b) Fluorescence emission spectra of $\mathbf{P N}-\mathbf{N}_{3}(20 \mu \mathrm{M})$ after addition of $\mathrm{H}_{2} \mathrm{~S}$ in $\mathrm{CH}_{3} \mathrm{CN} / \mathrm{H}_{2} \mathrm{O}\left(1: 8, \mathrm{v} / \mathrm{v} ; \mathrm{pH} 7.0 ; \lambda_{\max }=435 \mathrm{~nm}\right)$. (Inset) Fluorescence turn-on of $\mathbf{P N}-\mathbf{N}_{3}$ after addition of $\mathrm{H}_{2} \mathrm{~S}$. (c) Fluorescence intensity plot of probe $\mathbf{P N}-\mathbf{N}_{3}$ as a function of time. (d) Pseudo-first-order kinetics plot for the reaction of PN- $\mathbf{N}_{3}$ with $\mathrm{H}_{2} \mathrm{~S}$.

1,8-naphthalic anhydride. The $\mathbf{P N}-\mathbf{N}_{3}$ structure was confirmed by ${ }^{1} \mathrm{H} \mathrm{NMR},{ }^{13} \mathrm{C} \mathrm{NMR}$, and mass spectral studies (Figures S1-S5, Supporting information).

\section{RESULTS AND DISCUSSION}

Spectral Behavior of PN-N $\mathrm{N}_{3}$ with $\mathrm{H}_{2} \mathrm{~S}$. Absorbance and fluorescence titration spectra of $\mathbf{P N}-\mathbf{N}_{3}$ with $\mathrm{H}_{2} \mathrm{~S}$ up to 20 equiv were recorded in $\mathrm{CH}_{3} \mathrm{CN} / \mathrm{H}_{2} \mathrm{O}(1: 8, \mathrm{v} / \mathrm{v} ; \mathrm{pH} 7.0 ; 10$ $\mathrm{mM}$ phosphate-buffered saline). From Figure 1a, it has been observed that during successive addition of $\mathrm{H}_{2} \mathrm{~S}$, absorbance at $370 \mathrm{~nm}$ has been decreased along with an increase at $435 \mathrm{~nm}$. Two clear isosbestic points at 293 and $401 \mathrm{~nm}$ support the formation of a new compound in the reaction between $\mathbf{P N}-\mathbf{N}_{3}$ and $\mathrm{H}_{2} \mathrm{~S}$. A bathochromic shift of about $65 \mathrm{~nm}(370 \rightarrow 435$ $\mathrm{nm}$ ) in absorbance spectra describes the nucleophilic addition of $\mathrm{H}_{2} \mathrm{~S}$ to the azide moiety, which produces highly fluorescent PN- $\mathbf{N H}_{2}$ by blocking the intramolecular charge transfer (ICT) process. About 3-fold enhanced absorbance of $\mathbf{P N}-\mathbf{N H}_{2}$ compared to that of $\mathbf{P N}-\mathbf{N}_{3}$ has been noted at $435 \mathrm{~nm}$ upon saturation with $\mathrm{H}_{2} \mathrm{~S}$ (Figure S6). Fluorimetric titration reveals that a $20 \mu \mathrm{M}$ solution of $\mathbf{P N}-\mathbf{N}_{3}$ is weakly fluorescent $(\Phi=$ 0.056 ) but an addition of 20 equiv $\mathrm{H}_{2} \mathrm{~S}$ hiked up to 5-fold ( $\Phi^{*}$ $=0.314$ ) turn-on response. A slight red shift from 517 to 524 $\mathrm{nm}\left(\lambda_{\max }=435 \mathrm{~nm}\right)$ (Figure $\left.1 \mathrm{~b}\right)$ is probably due to the vibrant $\mathrm{n}-\pi^{*}$ transition in the naphthalimide moiety of $\mathbf{P N}-\mathrm{NH}_{2}$.

$\mathrm{pH}$ titration shows that $\mathbf{P N}-\mathbf{N}_{3}$ is independent of the $\mathrm{pH}$ of the solution, whereas $\mathbf{P N}-\mathbf{N H}_{2}$ becomes nonfluorescent under acidic $\mathrm{pH}$ due to protonation of the $-\mathrm{NH}_{2}$ group (Figure S7). The detection limit of $\mathbf{P N}-\mathbf{N}_{3}$ for $\mathrm{H}_{2} \mathrm{~S}$ was measured to be 66 $\mathrm{nM}$ (Figure S8). Job's plot analysis indicated 1:2 stoichiometric interaction of $\mathbf{P N}-\mathbf{N}_{3}$ with $\mathrm{H}_{2} \mathrm{~S}$ to give $\mathbf{P N}-\mathbf{N H}_{2}$ (Figure S9). The kinetic profiles showed the completion of the reaction between $\mathbf{P N}-\mathrm{N}_{3}$ and $\mathrm{H}_{2} \mathrm{~S}$ within 90 s (Figure 1c). The pseudo-first-order rate constant $\left(k^{\prime}\right)$ has been calculated as $k^{\prime}$ $=0.02 \mathrm{~s}^{-1}$ (Figure 1d) according to the equation ${ }^{61}$

$$
\ln \left[\left(F_{\max }-F_{\mathrm{t}}\right) / F_{\max }\right]=-k^{\prime} t
$$

where $F_{\mathrm{t}}$ and $F_{\max }$ are the fluorescence intensities at $524 \mathrm{~nm}$ $\left(\lambda_{\mathrm{ex}}=435 \mathrm{~nm}\right)$ at time " $t$ " and the maximum value obtained after the reaction is complete, respectively, and $k^{\prime}$ is the observed pseudo-first-order rate constant.

Selectivity of $\mathrm{PN}-\mathrm{N}_{3}$. Before moving to other relevant experiments, we checked the selectivity of $\mathbf{P N}-\mathbf{N}_{3}$ toward $\mathrm{H}_{2} \mathrm{~S}$. The addition of various anions $\left(\mathrm{HPO}_{4}{ }^{2-}, \mathrm{HCO}_{3}^{-}, \mathrm{OAc}^{-}, \mathrm{F}^{-}\right.$, $\mathrm{Cl}^{-}, \mathrm{S}_{2} \mathrm{O}_{3}{ }^{-}, \mathrm{S}_{2} \mathrm{O}_{4}{ }^{2-}, \mathrm{SO}_{3}{ }^{2-}, \mathrm{SO}_{4}{ }^{2-}$ ) and biologically relevant ROS, RNS such as $\mathrm{H}_{2} \mathrm{O}_{2}$ and $\mathrm{NO}$, along with ascorbic acid and L-cysteine, to the colorless solution of $\mathbf{P N}-\mathbf{N}_{3}$ did not show any changes, whereas the addition of $\mathrm{H}_{2} \mathrm{~S}$ turned immediately the colorless clear solution into lemon yellow. A strong green fluorescence has been shown for $\mathrm{H}_{2} \mathrm{~S}$ when a similar test was performed under a UV lamp, but in the presence of other anions, ROS, RNS, and L-cysteine, the solution endured its inherent non-fluorescence (Figure S10a). Sensitivity of $\mathbf{P N}-\mathbf{N}_{3}$ toward $\mathrm{H}_{2} \mathrm{~S}$ in the gas phase was well accomplished by the dip stick method. The paper strips were soaked in the probe solution and exhibited bright lemon yellow color just after contacting with $\mathrm{H}_{2} \mathrm{~S}$ (Figure $\mathrm{S} 10 \mathrm{~b}$ ). This observation was also justified by absorbance and fluorescence titration studies (Figure S11).

NMR and Mass Titration. ${ }^{1} \mathrm{H}$ NMR titration was executed in $\mathrm{CD}_{3} \mathrm{CN}$ (Figure S12) to illustrate the interactions of $\mathbf{P N}-\mathbf{N}_{3}$ with $\mathrm{H}_{2} \mathrm{~S}$. After the gradual addition of $\mathrm{H}_{2} \mathrm{~S}$ to the probe, a new characteristic peak of the aromatic amine functional group was developed between 5.0 and $5.2 \mathrm{ppm}$. The conversion of azide to amine in the presence of 2 equiv of $\mathrm{H}_{2} \mathrm{~S}$ made $\mathbf{P N}-\mathbf{N H}_{2}$ more electron-rich and consequently the entire aromatic region shifted to upfield a little bit. The mass spectrum of 
the reaction mixture of $\mathbf{P N}-\mathbf{N}_{3}$ and $\mathrm{H}_{2} \mathrm{~S}$ has also been recorded, which gives a new peak at $m / z: 317.2134$, specifying the formation of $\mathbf{P N}-\mathbf{N H}_{2}$ (Figure S13).

Theoretical Analysis. We performed time-dependent density functional theory (TD-DFT) calculations for the reactant and the product also (Figure S14). The investigation was done by quantum chemical calculations at the DFT level using the $6-311 \mathrm{G}+(\mathrm{d}, \mathrm{p})$ basis set implemented in Gaussian 09 program. Solvent effects were incorporated using a CPCM solvent model (Tables S2 and S3).

The vertical electronic transitions, i.e., the calculated $\lambda_{\max }$ orbital transition, and oscillator strength (f), are listed in Tables S4, S5 and Figure S15. Provided transitions at $285 \mathrm{~nm}$ in $\mathbf{P N}-\mathbf{N}_{3}, 288 \mathrm{~nm}$ and $408 \mathrm{~nm}$ in $\mathbf{P N}-\mathbf{N H}_{2}$ indicate the formation of two prominent isosbestic points in absorbance titration. The major transition in $\mathbf{P N}-\mathbf{N}_{3}$ at $376 \mathrm{~nm}\left(\mathrm{~S}_{0} \rightarrow \mathrm{S}_{1}, f\right.$ $=0.8193)$ is very close to that observed at $370 \mathrm{~nm}$ experimentally. Lowering of the curve in titration signifies the termination of ICT. Furthermore, the energy gap between the highest occupied molecular orbital (HOMO) and lowest unoccupied molecular orbital (LUMO) of $\mathbf{P N}-\mathbf{N}_{3}$ is smaller than that of $\mathbf{P N}-\mathbf{N H}_{2}$, in good agreement with the greater stability of the latter (Figure 2). This theoretical study strongly correlates with the experimental findings.

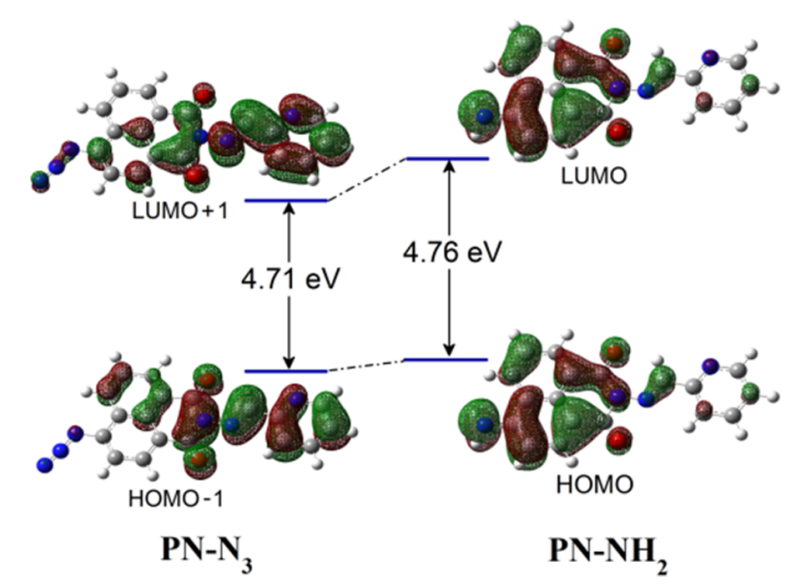

Figure 2. HOMO-LUMO distributions of $\mathbf{P N}-\mathbf{N}_{3}$ and $\mathbf{P N}-\mathbf{N H}_{2}$

Potential Energy Surface (PES) Calculation. We also acquired the energies of different probable intermediates from potential energy surface (PES) calculations (Figure 3). ${ }^{62}$

The highest energy $(17.5 \mathrm{kcal} / \mathrm{mol})$ occupying intermediate $\mathbf{2}$ has been achieved after the nucleophilic attack on $\mathbf{P N}-\mathbf{N}_{3}$ by the hydrosulfide $\left(\mathrm{HS}^{-}\right)$ion. Then, the thermodynamically most stable $(-70.3 \mathrm{kcal} / \mathrm{mol})$ product $\mathbf{P N}-\mathbf{N H}_{2}$ is formed via anionic intermediate 3 .

Plausible Mechanism and Explanation. From all of the experimental and computational investigations outlined above, a plausible mechanism for $\mathrm{HS}^{-}$-mediated reduction of $\mathbf{P N}-\mathbf{N}_{3}$ (Scheme 1) has been defined. On the basis of the high nucleophilicity of $\mathrm{HS}^{-}$(obtained from aq $\mathrm{Na}_{2} \mathrm{~S}$ solution), it may be the active species required for azide reduction, rather than $\mathrm{H}_{2} \mathrm{~S}$.

$\mathbf{P N}-\mathbf{N}_{3}$ is weakly fluorescent, signifying the intramolecular charge transfer (ICT) from the pyridine to the naphthalimide moiety. In the first step of this reaction (Scheme S1), a nucleophilic attack of $\mathrm{HS}^{-}$occurs on the electrophilic center, i.e., the azide nitrogen of $\mathbf{P N}-\mathbf{N}_{3}$, to produce anionic azidothiol

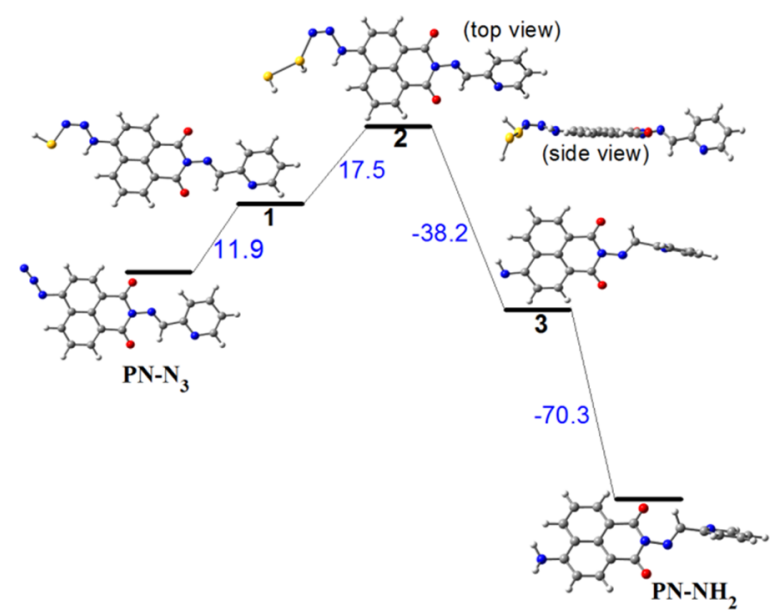

Figure 3. Calculated potential energy surfaces for the plausible mechanism of formation of $\mathbf{P N}-\mathbf{N H}_{2}$ from $\mathbf{P N}-\mathbf{N}_{3}$. Energies are reported in $\mathrm{kcal} / \mathrm{mol}$.

intermediate $\mathbf{1}$, which is then rapidly protonated to form more electrophilic and neutral intermediate 2 , ensuing the closure of ICT. Consequent attack of second equivalent of $\mathrm{HS}^{-}$on 2 produces deprotonated resonance-stabilized amine 3 , which benefits a sharp $n-\pi^{*}$ transition in the naphthalimide moiety. Finally, the proton transfer facilitated by the solvent water results in the formation of strong fluorescent $\mathbf{P N}-\mathbf{N H}_{2}$.

Quantitative Analysis. For comparative studies on the consumption of $\mathrm{H}_{2} \mathrm{~S}$ in human body through nutrients, food samples were arbitrarily chosen from our daily diet, such as chicken, egg, fish, radish, soybean, and cauliflower. ${ }^{63,64}$ All of the samples except egg had been washed, cut into pieces, and set to boil in distilled water. In case of eggs, egg white was separated and boiled. The vapor produced from the food sample was allowed to come in contact of filter paper strips coated with our probe $\mathbf{P N}-\mathbf{N}_{3}$ (Figure 4). The colorimetric changes in the strips were observed and recorded during $2 \mathrm{~h}$ with 30 min time interval.

The concentration of $\mathrm{H}_{2} \mathrm{~S}$ produced from the chosen food samples was estimated on the basis of fluorimetric analysis. The difference between the fluorescence intensities of the paper strips at different time intervals could give a clear idea about whether the food samples can provide a higher, moderate, or lower amount of $\mathrm{H}_{2} \mathrm{~S}$ after its consumption by the living system (Figure 5a).

Three paper strips soaked with $\mathbf{P N}-\mathbf{N}_{3}$ were allowed to keep contact with the exposure in commercially available $\mathrm{Na}_{2} \mathrm{~S}$ solutions to display the different fluorescence intensities, indicating three different ranges of concentrations (Figure S16). Hence, a standard curve was obtained by plotting the fluorescence intensity of $\mathbf{P N}-\mathbf{N}_{3}$ with $\mathrm{Na}_{2} \mathrm{~S}$ with the respective concentration of $\mathrm{H}_{2} \mathrm{~S}$ evolved (Figure $5 \mathrm{~b}$ ). This concentration versus fluorescence intensity graph could easily represent the amount of $\mathrm{H}_{2} \mathrm{~S}$ produced from the food samples after their consumption by the living system, and here it was found to be in the range of $0.5-1.4 \mu \mathrm{M}$. A colorimetric assay has also been carried out with the help of the absorbance plot to further validate the fluorimetric estimation data (Figure S17).

\section{CONCLUSIONS}

In summary, we have successfully developed a new chemosensing method for comparative quantitative analysis of $\mathrm{H}_{2} \mathrm{~S}$ 
Scheme 1. Fluorescence Turn-On of $\mathrm{PN}^{-N_{3}}$ after Addition of $\mathrm{H}_{2} \mathrm{~S}$

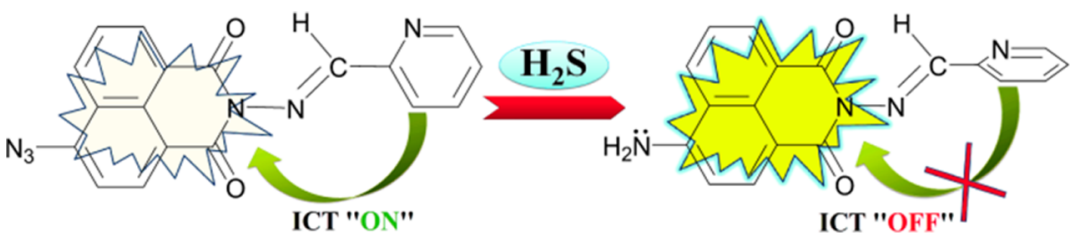

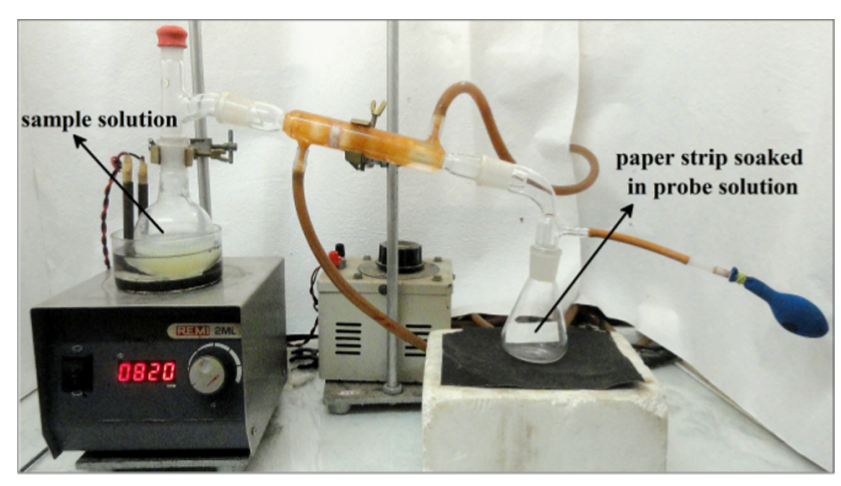

Figure 4. Apparatus setup for analysis of $\mathrm{H}_{2} \mathrm{~S}$ produced from dietary samples.

(a)

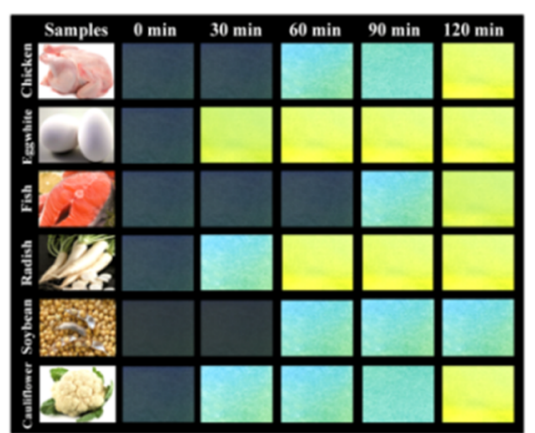

(b)

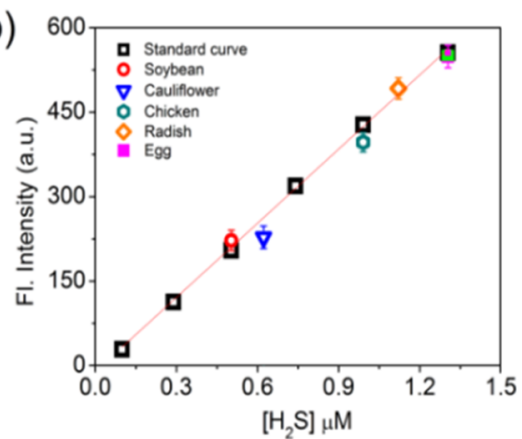

Figure 5. (a) Images of filter paper strips after consumption of $\mathrm{H}_{2} \mathrm{~S}$ vapor produced from food samples at $30 \mathrm{~min}$ interval. (b) Estimation of the concentration of $\mathrm{H}_{2} \mathrm{~S}$ produced from the food samples following the standard curve. Standard deviations (SDs) are given by error bars, where $n=3$.

produced by food samples from our daily diet. The chemodosimeter $\mathbf{P N}-\mathbf{N}_{3}$ can selectively detect $\mathrm{H}_{2} \mathrm{~S}$ at nanomolar range giving a vivid colorimetric and fluorimetric response in both solution and gaseous phases. The potentiality of $\mathbf{P N}-\mathbf{N}_{3}$ is that it could be treated as a simple, less-timeconsuming, cost-effective practical sensing system for determining $\mathrm{H}_{2} \mathrm{~S}$ in biological samples. Our probe can also be used in pathological applications by developing an analyzing tool to detect the abnormal endogenous $\mathrm{H}_{2} \mathrm{~S}$ level, which is responsible for various diseases.

\section{EXPERIMENTAL SECTION}

Materials and Instruments. 4-Bromo-1,8-naphthalic anhydride, hydrazine hydrate, picolinaldehyde, sodium azide, chloroform, 2,2-dimethylformamide (DMF), ethanol, all of the anions, L-cysteine, homocysteine, glutathione and all other chemicals were purchased from Sigma-Aldrich Pvt. Ltd. (India) and obtained from commercial suppliers. All of the materials were used directly as purchased. The solvents were dried, maintaining the conditions of standard procedures. Elix Millipore water was used throughout the experiments. A Bruker $400 \mathrm{MHz}$ instrument was employed for detailing ${ }^{1} \mathrm{H}$ and ${ }^{13} \mathrm{C}$ NMR spectra with the solvents $\mathrm{CD}_{3} \mathrm{CN}, \mathrm{CDCl}_{3}$, dimethyl sulfoxide (DMSO) $-d_{6}$ and $\mathrm{D}_{2} \mathrm{O}$. Tetramethylsilane was used as an internal standard. Chemical shifts are given in $\delta$ ppm units and ${ }^{1} \mathrm{H}-{ }^{1} \mathrm{H}$ and ${ }^{1} \mathrm{H}-\mathrm{C}$ coupling constants in Hertz. The following abbreviations are used to describe spin multiplicities in ${ }^{1} \mathrm{H}$ NMR spectra: $s$, singlet; $d$, doublet; $t$, triplet; and $\mathrm{m}$, multiplet. A micromass Q-TOF micro instrument was used to record the mass spectrum using methanol as the solvent. A PerkinElmer model LS55 spectrophotometer and a Shimadzu UV-3101PC spectrophotometer were used for recording fluorescence and UV-vis spectra, respectively. A PerkinElmer 2400 series CHNS/O analyzer was used for elemental analysis of the compounds.

Synthesis of 1. Following a published procedure, compound 1 was synthesized. ${ }^{65}$ 4-Bromo-1,8-naphthalic anhydride $(1 \mathrm{~g}, 5.0 \mathrm{mmol})$ was stirred at room temperature in chloroform $(10 \mathrm{~mL})$ for $15 \mathrm{~min}$, and then excess $(3 \mathrm{~mL})$ of hydrazine hydrate was added. The reaction mixture was then refluxed for $12 \mathrm{~h}$ and monitored with thin-layer chromatography (TLC). After cooling, a yellow solid was obtained, which was then filtered and dried at $100{ }^{\circ} \mathrm{C}$. Yield: $90 \%$. ${ }^{1} \mathrm{H}$ NMR $\left(\mathrm{CDCl}_{3}, 400 \mathrm{MHz}\right): \delta(\mathrm{ppm}): 8.65-8.67(\mathrm{~m}, 1 \mathrm{H}, J=8 \mathrm{~Hz})$, $8.57-8.59(\mathrm{~m}, 1 \mathrm{H}, J=8 \mathrm{~Hz}), 8.41-8.43(\mathrm{~d}, 1 \mathrm{H}, J=8 \mathrm{~Hz})$, $8.03-8.05(\mathrm{~d}, 1 \mathrm{H}, J=8 \mathrm{~Hz}), 7.83-7.87(\mathrm{~m}, 1 \mathrm{H}, J=16 \mathrm{~Hz})$, $5.52(\mathrm{~s}, 2 \mathrm{H}) .{ }^{13} \mathrm{C} \mathrm{NMR}\left(\mathrm{CDCl}_{3}, 400 \mathrm{MHz}\right): \delta(\mathrm{ppm}): 160.51$, 133.96, 132.50, 131.63, 131.39, 131.08, 130.81, 128.33, 127.81, 122.50, 121.57, 77.48, 77.16, 76.84. Anal. Calcd for $\mathrm{C}_{12} \mathrm{H}_{7} \mathrm{~N}_{2} \mathrm{O}_{2} \mathrm{Br}$ : C, 49.51; H, 2.42; N, 9.62; O, 10.99; found: C, 49.23; H, 2.51; N, 9.82; O, 11.00 .

Synthesis of 2. Compound $\mathbf{1}$ and picolinaldehyde were dissolved in ethanol and refluxed for $24 \mathrm{~h}$, monitoring with TLC. The solvent was evaporated under reduced pressure, and the crude product compound 2 was further purified by column chromatography $\left(\mathrm{CHCl}_{3} / \mathrm{EtOAc}=6: 1\right)$. Yield: $82 \% .{ }^{1} \mathrm{H}$ NMR $\left(\mathrm{CDCl}_{3}, 400 \mathrm{MHz}\right): \delta(\mathrm{ppm}): 8.73(\mathrm{~s}, 3 \mathrm{H}), 8.62-8.72(\mathrm{~m}$, $1 \mathrm{H}, J=40 \mathrm{~Hz}), 8.48-8.50(\mathrm{~d}, 1 \mathrm{H}, J=8 \mathrm{~Hz}), 7.38-7.40(\mathrm{~d}$, $1 \mathrm{H}, J=8 \mathrm{~Hz}), 8.07-8.09(\mathrm{~d}, 1 \mathrm{H}, J=8 \mathrm{~Hz}), 7.83-7.91(\mathrm{~m}$, $2 \mathrm{H}, J=32 \mathrm{~Hz}), 7.26-7.46(\mathrm{~m}, 1 \mathrm{H}, J=8 \mathrm{~Hz}) .{ }^{13} \mathrm{C}$ NMR $\left(\mathrm{CDCl}_{3}, 400 \mathrm{MHz}\right): \delta$ (ppm): 171.28, 150.03, 136.85, 133.94, 132.93, 132.05, 131.46, 128.41, 126.22, 122.70, 77.47, 77.15, 
76.83. Anal. Calcd for $\mathrm{C}_{18} \mathrm{H}_{10} \mathrm{~N}_{3} \mathrm{O}_{2} \mathrm{Br}$ : C, 56.86; H, 2.65; N, 11.05; O, 8.42; found: C, 56.81; H, 2.68; N, 11.02; O, 8.39.

Synthesis of $\mathbf{P N}-\mathbf{N}_{3}$. To produce $\mathbf{P N}-\mathbf{N}_{3}$ (Scheme 2), sodium azide was dissolved in dried DMF, followed by

Scheme 2. Stepwise Preparation of the PN-N3 Probe

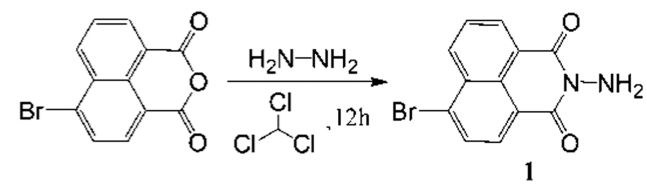

1

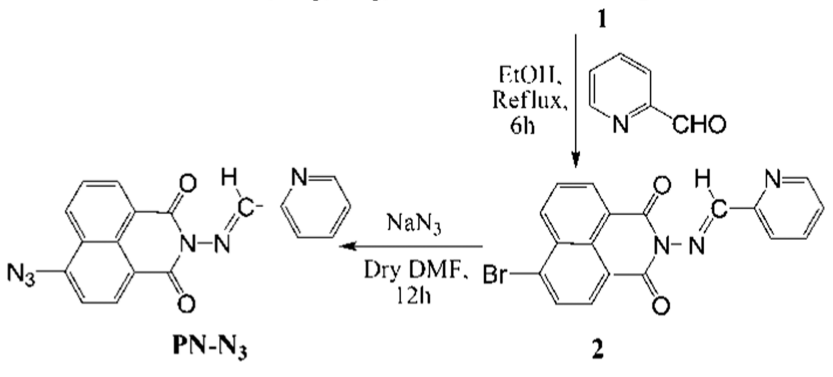

addition of compound 2 after 1 h. The reaction mixture was stirred at $50{ }^{\circ} \mathrm{C}$ under a nitrogen atmosphere, monitoring with TLC. After the consumption of starting material, the reaction mixture was treated with ice cold water and filtered under reduced pressure. The yellow solid residue obtained was washed with cold water and further used. Melting point 180 ${ }^{\circ} \mathrm{C}$. Yield: $82 \%$. ${ }^{1} \mathrm{H}$ NMR (DMSO- $\left.d_{6}, 400 \mathrm{MHz}\right): \delta(\mathrm{ppm})$ : $8.79(\mathrm{~s}, 2 \mathrm{H}), 8.48-8.60(\mathrm{~m}, 3 \mathrm{H}), 8.25-8.27(\mathrm{~d}, 1 \mathrm{H}, J=8 \mathrm{~Hz})$, $8.03-8.07(\mathrm{t}, 1 \mathrm{H}, J=16 \mathrm{~Hz}), 7.88-7.93(\mathrm{~m}, 1 \mathrm{H}, J=20 \mathrm{~Hz})$, $7.77-7.81(\mathrm{t}, 1 \mathrm{H}, J=16 \mathrm{~Hz}), 7.63-7.66(\mathrm{t}, 1 \mathrm{H}, J=12 \mathrm{~Hz})$. ${ }^{13} \mathrm{C}$ NMR (DMSO- $\left.d_{6}, 400 \mathrm{MHz}\right): \delta$ (ppm): 171.91, 151.23, $150.14,143.33,137.45,132.05,131.96,131.67,128.69,127.46$, $126.65,122.57,121.85,116.16,40.13,39.92,39.71,39.51$, 39.29, 39.09, 38.88. Anal. Calcd for $\mathrm{C}_{18} \mathrm{H}_{10} \mathrm{~N}_{6} \mathrm{O}_{2}$ : C, 63.16; $\mathrm{H}$, 2.94; N, 24.55; O, 9.35; found: C, 63.11; H, 2.96; N, 24.52; O, 9.35. Matrix-assisted laser desorption ionization (time-of-flight mass spectrometry): Anal. Calcd for $\mathrm{C}_{18} \mathrm{H}_{10} \mathrm{~N}_{6} \mathrm{O}_{2}$ : 342.09; found: $343.09\left[\mathrm{M}+\mathrm{H}^{+}\right], 100 \%$.

Absorbance and Fluorescence Studies. A stock solution of $\mathbf{P N}-\mathbf{N}_{3}(20 \mu \mathrm{M})$ was prepared in acetonitrilewater. $\mathrm{A}_{2} \mathrm{~S}$ solution (from $\mathrm{Na}_{2} \mathrm{~S}$ ) of concentration $100 \mu \mathrm{M}$ was prepared in Elix Millipore water. All experiments were carried out using $\mathrm{CH}_{3} \mathrm{CN} / \mathrm{H}_{2} \mathrm{O}(1: 8, \mathrm{v} / \mathrm{v})$ maintaining the $\mathrm{pH}$ at 7.0 (10 $\mathrm{mM}$ phosphate buffer). During the titration, in the quartz optical cell of $1 \mathrm{~cm}$ optical path length, each time, a 20 $\mu \mathrm{M}$ solution of $\mathbf{P N}-\mathrm{N}_{3}$ was filled and a stock solution of $\mathrm{Na}_{2} \mathrm{~S}$ was gradually added into it until saturation. After 1-2 min of the addition of $\mathrm{H}_{2} \mathrm{~S}$ solution, spectral data were recorded. For all fluorescence measurements, excitation was provided at 435 $\mathrm{nm}$ and emission was collected between 485 and $580 \mathrm{~nm}$.

Measurement of Fluorescence Quantum Yield. The fluorescence quantum yields (QY) of $\mathbf{P N}-\mathbf{N}_{3}(\Phi)$ and PN$\mathrm{NH}_{2}\left(\Phi^{*}\right)$ were determined relative to a reference compound fluorescein $\left(\Phi_{\mathrm{r}}=0.95\right.$ in $\left.0.1 \mathrm{M} \mathrm{NaOH}\right)$ at $\mathrm{pH} 7.0(10 \mathrm{mM}$ phosphate buffer). The same excitation wavelength, gain, and slit band widths were applied for both samples. The QY was calculated using the following equation ${ }^{66}$

$$
\Phi=\left[\left(A_{\mathrm{r}} \mathrm{FA}_{\mathrm{s}} \eta^{2}\right) /\left(A_{\mathrm{s}} \mathrm{FA}_{\mathrm{r}} \eta_{0}^{2}\right)\right] \Phi_{\mathrm{r}}
$$

where $A_{\mathrm{r}}$ and $A_{\mathrm{s}}$ are the absorbance of the reference and sample solution at the reference excitation wavelength, $\mathrm{FA}_{\mathrm{r}}$ and
$\mathrm{FA}_{\mathrm{s}}$ are the corresponding integrated fluorescence intensities, and $\eta$ and $\eta_{0}$ are the solvent refractive indexes of the sample and reference, respectively.

Calculation of Limit of Detection (LOD). From the fluorescence titration data, the detection limit of $\mathbf{P N}-\mathbf{N}_{3}$ for $\mathrm{H}_{2} \mathrm{~S}$ was calculated. The standard deviation for the fluorescence intensity was determined from the measurements of the emission intensity of four individual receptors without $\mathrm{H}_{2} \mathrm{~S} 10$ times. The evaluation was done by following the equation $^{67}$

$$
\mathrm{LOD}=K \times \mathrm{SD} / S
$$

where $K=2$ or 3 (here, we took 3 ), SD is the standard deviation of the blank receptor solution, and $S$ is the slope of the calibration curve.

\section{ASSOCIATED CONTENT}

\section{Supporting Information}

The Supporting Information is available free of charge on the ACS Publications website at DOI: 10.1021/acsomega.8b01751.

${ }^{1} \mathrm{H}$ NMR, ${ }^{13} \mathrm{C}$ NMR, and MS spectra; additional spectroscopic data; supplementary fluorescence images; and theoretical calculation tables (PDF)

\section{AUTHOR INFORMATION}

\section{Corresponding Author}

*E-mail: prithidipa@hotmail.com.

ORCID $\odot$

Sujoy Das: 0000-0003-3921-0999

Himadri S. Sarkar: 0000-0003-4638-5826

Prithidipa Sahoo: 0000-0001-8493-7068

\section{Author Contributions}

${ }^{\dagger}$ A.G. and S.D. contributed equally to this work.

Notes

The authors declare no competing financial interest.

\section{ACKNOWLEDGMENTS}

Acknowledgments are given to SERB-DST, Govt. of India, by P.S. for her research grant [Project file no. SB/FT/CS-021/ 2014]. A.G. and S.D. are grateful to UGC and CSIR, India, respectively, for their research fellowship.

\section{REFERENCES}

(1) Bailey, T. S.; Pluth, M. D. Chemiluminescent Detection of Enzymatically Produced Hydrogen Sulfide: Substrate Hydrogen Bonding Influences Selectivity for $\mathrm{H}_{2} \mathrm{~S}$ over Biological Thiols. J. Am. Chem. Soc. 2013, 135, 16697-16704

(2) Wan, Q.; Song, Y.; Li, Z.; Gao, X.; Ma, H. In vivo monitoring of hydrogen sulfide using a cresyl violet-based ratiometric fluorescence probe. Chem. Commun. 2013, 49, 502-504.

(3) Abe, K.; Kimura, H. The possible role of hydrogen sulfide as an endogenous neuromodulator. J. Neurosci. 1996, 16, 1066-1071.

(4) Kimura, H.; Nagai, Y.; Umemura, K.; Kimura, Y. Physiological roles of hydrogen sulfide: synaptic modulation, neuroprotection and smooth muscle relaxation. Antioxid. Redox Signaling 2005, 7, 795803.

(5) Ritter, J. M. Human pharmacology of hydrogen sulfide, putative gaseous mediator. Br. J. Clin. Pharmacol. 2010, 69, 573-575.

(6) Wang, R. Physiological implications of hydrogen sulfide: a whiff exploration that blossomed. Physiol. Rev. 2012, 92, 791-896.

(7) Wang, R. The gasotransmitter role of hydrogen sulfide. Antioxid. Redox Signaling 2003, 5, 493-501. 
(8) Singh, S.; Padovani, D.; Leslie, R. A.; Chiku, T.; Banerjee, R. Relative contribution of cystathionine-synthase and -cystathionase to $\mathrm{H}_{2} \mathrm{~S}$ biogenesis via alternative trans-sulfuration reactions. J. Biol. Chem. 2009, 284, 22457-22466.

(9) Chiku, T.; Padovani, D.; Zhu, W.; Singh, S.; Vitvitsky, V.; Banerjee, R. $\mathrm{H}_{2} \mathrm{~S}$ biogenesis by human cystathionine gamma-lyase leads to the novel sulfur metabolites lanthionine and homolanthionine and is responsive to the grade of hyperhomocysteinemia. J. Biol. Chem. 2009, 284, 11601-11612.

(10) Lin, V. S.; Chang, C. J. Fluorescent probes for sensing and imaging biological hydrogen sulfide. Curr. Opin. Chem. Biol. 2012, 16, 595-601.

(11) Shibuya, N.; Tanaka, M.; Yoshida, M.; Ogasawara, Y.; Togawa, T.; Ishii, K.; Kimura, H. 3-Mercaptopyruvate sulfurtransferase produces hydrogen sulfide and bound sulfane sulfur in the brain. Antioxid. Redox Signaling 2009, 11, 703-714.

(12) Figliuolo, V. R.; Dos Santos, L. M.; Abalo, A.; Nanini, H.; Santos, A.; Brittes, N. M.; Bernardazzi, C.; de Souza, H. S. P.; Vieira, L. Q.; Coutinho-Silva, R.; Coutinho, C. M. L. M. Sulfate-reducing bacteria stimulate gut immune responses and contribute to inflammation in experimental colitis. Life Sci. 2017, 189, 29-38.

(13) Papapetropoulos, A.; Pyriochou, A.; Altaany, Z.; Yang, G.; Marazioti, A.; Zhou, Z.; et al. Hydrogen sulfide is an endogenous stimulator of angiogenesis. Proc. Natl. Acad. Sci. U.S.A. 2009, 106, 21972-21977.

(14) Chen, Y. H.; Yao, W. Z.; Geng, B.; Ding, Y. L.; Lu, M.; Zhao, M. W.; Tang, C. S. Endogenous hydrogen sulfide in patients with COPD. Chest 2005, 128, 3205-3211.

(15) Baskar, R.; Bian, J. Hydrogen sulfide gas has cell growth regulatory role. Eur. J. Pharmacol. 2011, 656, 5-9.

(16) Yang, G.; Wu, L.; Jiang, B.; Yang, W.; Qi, J.; Cao, K.; Meng, Q.; Mustafa, A. K.; Mu, W.; Zhang, S.; Snyder, S. H.; Wang, R. $\mathrm{H}_{2} \mathrm{~S}$ as a physiologic vasorelaxant: hypertension in mice with deletion of cystathionine gamma-lyase. Science 2008, 322, 587-590.

(17) Cai, Y.; Li, L.; Wang, Z.; Sun, J. Z.; Qin, A.; Tang, B. Z. A sensitivity tunable tetraphenylethene-based fluorescent probe for directly indicating the concentration of hydrogen sulfide. Chem. Commun. 2014, 50, 8892-8895.

(18) Calvert, J. W.; Jha, S.; Gundewar, S.; Elrod, J. W.; Ramachandran, A.; Pattillo, C. B.; Kevi, C. G.; Lefer, D. J. Hydrogen Sulfide Mediates Cardioprotection Through Nrf2 Signaling. Circ. Res. 2009, 105, 365-374.

(19) Martelli, A.; Testai, L.; Breschi, M. C.; Blandizzi, C.; Virdis, A.; Taddei, S.; Calderone, V. Hydrogen sulphide: novel opportunity for drug discovery. Med. Res. Rev. 2012, 32, 1093-1130.

(20) Mancardi, D.; Penna, C.; Merlino, A.; Del Soldato, P.; Wink, D. A.; Pagliaro, P. Physiological and pharmacological features of the novel gasotransmitter: hydrogen sulfide. Biochim. Biophys. Acta 2009, 1787, 864-872.

(21) Li, L.; Rose, P.; Moore, P. K. Hydrogen sulfide and cell signaling. Annu. Rev. Pharmacol. Toxicol. 2011, 51, 169-187.

(22) d'Emmanuele di Villa Bianca, R.; Sorrentino, R.; Maffia, P.; Mirone, V.; Imbimbo, C.; Fusco, F.; De Palma, R.; Ignarro, L. J.; Cirino, G. Hydrogen sulfide as a mediator of human corpus cavernosum smooth-muscle relaxation. Proc. Natl. Acad. Sci. U.S.A. 2009, 106, 4513-4518.

(23) Hoffman, M. Hydrogen Sulfide: Potential help for ED. WebMD, March 2, 2009.

(24) Boehning, D.; Snyder, S. H. Novel neural modulators. Annu. Rev. Neurosci. 2003, 26, 105-131.

(25) Kimura, H. Hydrogen sulfide as a neuromodulator. Mol. Neurobiol. 2002, 26, 13-19.

(26) Mao, G. J.; Wei, T. T.; Wang, X. X.; Huan, S. Y.; Lu, D. Q.; Zhang, J.; Zhang, X. B.; Tan, W.; Shen, G. L.; Yu, R. Q. HighSensitivity Naphthalene-Based Two-Photon Fluorescent Probe Suitable for Direct Bio-imaging of $\mathrm{H}_{2} \mathrm{~S}$ in Living Cells. Anal. Chem. 2013, 85, 7875-7881.
(27) Yang, W.; Yang, G.; Jia, X.; Wu, L.; Wang, R. Activation of KATP channels by $\mathrm{H}_{2} \mathrm{~S}$ in rat insulin-secreting cells and the underlying mechanisms. J. Physiol. 2005, 569, 519-531.

(28) Jiang, B.; Tang, G.; Cao, K.; Wu, L.; Wang, R. Molecular mechanism for $\mathrm{H}_{2} \mathrm{~S}$-induced activation of $\mathrm{K}$ (ATP) channels. Antioxid. Redox Signaling 2010, 12, 1167-1178.

(29) Sun, W. H.; Liu, F.; Chen, Y.; Zhu, Y. C. Hydrogen sulfide decreases the levels of ROS by inhibiting mitochondrial complex IV and increasing SOD activities in cardiomyocytes under ischemia/ reperfusion. Biochem. Biophys. Res. Commun. 2012, 421, 164-169.

(30) Eto, K.; Asada, T.; Arima, K.; Makifuchi, T.; Kimura, H. Brain hydrogen sulfide is severely decreased in Alzheimer's disease. Biochem. Biophys. Res. Commun. 2002, 293, 1485-1488.

(31) Ichinohe, A.; Kanaumi, T.; Takashima, S.; Enokido, Y.; Nagai, Y.; Kimura, H. Cystathionine $\beta$-synthase is enriched in the brains of Down's patients. Biochem. Biophys. Res. Commun. 2005, 338, 15471550.

(32) Hu, L. F.; Lu, M.; Tiong, C. X.; Dawe, G. S.; Hu, G.; Bian, J. S. Neuroprotective effects of hydrogen sulfide on Parkinson's disease rat models. Aging Cell 2010, 9, 135-146.

(33) King, A. L.; Polhemus, D. J.; Bhushan, S.; Otsuka, H.; Kondo, K.; Nicholson, C. K.; Bradley, J. M.; Islam, K. N.; Calvert, J. W.; Tao, Y. X.; Dugas, T. R.; Kelley, E. E.; Elrod, J. W.; Huang, P. L.; Wang, R.; Lefer, D. J. Hydrogen sulfide cytoprotective signaling is endothelial nitric oxide synthase-nitric oxide dependent. Proc. Natl. Acad. Sci. U.S.A. 2014, 111, 3182-3187.

(34) Adarsh, N.; Krishnan, M. S.; Ramaiah, D. Sensitive Naked Eye Detection of Hydrogen Sulfide and Nitric Oxide by Aza-BODIPY Dyes in Aqueous Medium. Anal. Chem. 2014, 86, 9335-9342.

(35) Reiffenstein, R. J.; Hulbert, W. C.; Roth, S. H. Toxicology of hydrogen sulfide. Annu. Rev. Pharmacol. Toxicol. 1992, 32, 109-134.

(36) Chen, C. Q.; Xin, H.; Zhu, Y. Z. Hydrogen sulfide: third gaseous transmitter, but with great pharmacological potential. Acta Pharmacol. Sin. 2007, 28, 1709-1716.

(37) Wang, R. Toxic Gas, Lifesaver. Sci. Am. 2010, 66-71.

(38) Kamoun, P. $\mathrm{H}_{2} \mathrm{~S}$, a new neuromodulator. Méd. Sci. 2004, 20, 697-700.

(39) Lawrence, N. S.; Deo, R. P.; Wang, J. J. Electrochemical determination of hydrogen sulfide at carbon nanotube modified electrodes. Anal. Chim. Acta 2004, 517, 131-137.

(40) Doeller, J. E.; Isbell, T. S.; Benavides, G.; Koenitzer, J.; Patel, H.; Patel, R. P.; Lancaster, J. R., Jr.; Darley-Usmar, V. M.; Kraus, D. W. Polarographic measurement of hydrogen sulfide production and consumption by mammalian tissues. Anal. Biochem. 2005, 341, 4051.

(41) Searcy, D. G.; Peterson, M. A. Hydrogen sulfide consumption measured at low steady state concentrations using a sulfidostat. Anal. Biochem. 2004, 324, 269-275.

(42) Richardson, C. J.; Magee, E. A.; Cummings, J. H. A new method for the determination of sulphide in gastrointestinal contents and whole blood by microdistillation and ion chromatography. Clin. Chim. Acta 2000, 293, 115-125.

(43) Furne, J.; Saeed, A.; Levitt, M. D. Whole tissue hydrogen sulfide concentrations are orders of magnitude lower than presently accepted values. Am. J. Physiol. 2008, 295, R1479-R1485.

(44) Radford-Knoery, J.; Cutter, G. A. Determination of carbonyl sulfide and hydrogen sulfide species in natural waters using specialized collection procedures and gas chromatography with flame photometric detection. Anal. Chem. 1993, 65, 976-982.

(45) Bérubé, P. R.; Parkinson, P. D.; Hall, E. R. Measurement of reduced sulphur compounds contained in aqueous matrices by direct injection into a gas chromatograph with a flame photometric detector. J. Chromatogr. A 1999, 830, 485-489.

(46) Lei, W.; Dasgupta, P. K. Determination of sulfide and mercaptans in caustic scrubbing liquor. Anal. Chim. Acta 1989, 226, 165.

(47) Hughes, M. N.; Centelles, M. N.; Moore, K. P. Making and working with hydrogen sulfide: The chemistry and generation of 
hydrogen sulfide in vitro and its measurement in vivo: a review. Free Radic. Biol. Med. 2009, 47, 1346-1353.

(48) Jiménez, D.; Martínez-Máñez, R.; Sancenón, F.; Ros-Lis, J. V.; Benito, A.; Soto, J. A New Chromo-chemodosimeter Selective for Sulfide Anion. J. Am. Chem. Soc. 2003, 125, 9000-9001.

(49) Lynn, E. G.; Austin, R. C. Hydrogen sulfide in the pathogenesis of atherosclerosis and its therapeutic potential. Expert Rev. Clin. Pharmacol. 2011, 4, 97-108.

(50) Ishigami, M.; Hiraki, K.; Umemura, K.; Ogasawara, Y.; Ishii, K.; Kimura, H. A source of hydrogen sulfide and a mechanism of its release in the brain. Antioxid. Redox Signaling 2009, 11, 205-214.

(51) Das, S.; Sarkar, H. S.; Uddin, M. R.; Rissanen, K.; Mandal, S.; Sahoo, P. Differential detection and quantification of cyclic AMP and other adenosine phosphates in live cells. Chem. Commun. 2017, 53, $7600-7603$.

(52) Liu, S.; Zhang, L.; Yang, T.; Yang, H.; Zhang, K. Y.; Zhao, X.; Lv, W.; Yu, Q.; Zhang, X.; Zhao, Q.; Liu, X.; Huang, W. Development of upconversion luminescent probe for ratiometric sensing and bioimaging of hydrogen sulfide. ACS Appl. Mater. Interfaces 2014, 6, 11013-11017.

(53) Wu, Z.; Liang, D.; Tang, X. Visualizing hydrogen sulfide in mitochondria and lysosome of living cells and in tumors of living mice with positively charged fluorescent chemosensors. Anal. Chem. 2016, $88,9213-9218$.

(54) Wu, Z.; Feng, Y.; Geng, B.; Liua, J.; Tang, X. Fluorogenic sensing of $\mathrm{H}_{2} \mathrm{~S}$ in blood and living cells via reduction of aromatic dialkylamino N-oxide. RSC Adv. 2014, 4, 30398-30401.

(55) Zhao, C.; Zhang, X.; Li, K.; Zhu, S.; Guo, Z.; Zhang, L.; Wang, F.; Fei, Q.; Luo, S.; Shi, P.; Tian, H.; Zhu, W.-H. Förster Resonance Energy Transfer Switchable Self-Assembled Micellar Nanoprobe: Ratiometric Fluorescent Trapping of Endogenous $\mathrm{H}_{2} \mathrm{~S}$ Generation via Fluvastatin-Stimulated Upregulation. J. Am. Chem. Soc. 2015, 137, 8490-8498.

(56) Peng, H.; Cheng, Y.; Dai, C.; King, A. L.; Predmore, B. L.; Lefer, D. J.; Wang, B. A fluorescent probe for fast and quantitative detection of hydrogen sulfide in blood. Angew. Chem., Int. Ed. 2011, 50, 9672-9675.

(57) Lippert, A. R.; New, E. J.; Chang, C. J. Reaction-based fluorescent probes for selective imaging of hydrogen sulfide in living cells. J. Am. Chem. Soc. 2011, 133, 10078-10080.

(58) Zhang, P.; Li, J.; Li, B.; Xu, J.; Zeng, F.; Lv, J.; Wu, S. A logic gate-based fluorescent sensor for detecting $\mathrm{H}_{2} \mathrm{~S}$ and $\mathrm{NO}$ in aqueous media and inside live cells. Chem. Commun. 2015, 51, 4414-4416.

(59) Zhou, G.; Wang, H.; Ma, Y.; Chen, X. A NBD fluorophorebased colorimetric and fluorescent chemosensor for hydrogen sulfide and its application for bioimaging. Tetrahedron 2013, 69, 867-870.

(60) Chen, T.; Zheng, Y.; Xu, Z.; Zhao, M.; Xu, Y.; Cui, J. A red emission fluorescent probe for hydrogen sulfide and its application in living cells imaging. Tetrahedron Lett. 2013, 54, 2980-2982.

(61) Sarkar, H. S.; Ghosh, A.; Das, S.; Maiti, P. K.; Maitra, S.; Mandal, S.; Sahoo, P. Visualisation of DCP, a nerve agent mimic, in Catfish brain by a simple chemosensor. Sci. Rep. 2018, 8, No. 3402.

(62) Henthorn, H. A.; Pluth, M. D. Mechanistic insights into the $\mathrm{H}_{2} \mathrm{~S}$-mediated reduction of aryl azides commonly used in $\mathrm{H}_{2} \mathrm{~S}$ detection. J. Am. Chem. Soc. 2015, 137, 15330-15336.

(63) Germs, A. C. Hydrogen sulphide production in eggs and egg products as a result of heating. J. Sci. Food Agric. 1973, 24, 7-16.

(64) Hussain, B.; Sultana, T.; Sultana, S.; Mahboob, S.; Farooq, M.; Al-Ghanim, K.; Nadeem, S. First report on fish cysteine as a biomarker of contamination in the river Chenab, Pakistan. Environ. Sci. Pollut. Res. 2016, 15495-15503.

(65) Wang, W.; Rusin, O.; Xu, X.; Kim, K. K.; Escobedo, J. O.; Fakayode, S. O.; Fletcher, K. A.; Lowry, M.; Schowalter, C. M.; Lawrence, C. M.; Fronczek, F. R.; Warner, I. M.; Strongin, R. M. Detection of homocysteine and cysteine. J. Am. Chem. Soc. 2005, 127, 15949-15958.

(66) Williams, A. T. R.; Winfield, S. A.; Miller, J. N. Relative fluorescence quantum yields using a computer-controlled luminescence spectrometer. Analyst 1983, 108, 1067-1071.
(67) Das, S.; Sarkar, H. S.; Uddin, M. R.; Mandal, S.; Sahoo, P. A chemosensor to recognize $\mathrm{N}$-acyl homoserine lactone in bacterial biofilm. Sens. Actuators, B 2018, 259, 332-338. 